\title{
PLAGIOTHECIUM PLATYPHYLLUM (BRYOPHYTA), A RARE SPECIES IN HUNGARY
}

\author{
Peter ErzbergeR ${ }^{1 *}$, Csaba Németh ${ }^{2}$, Michael SAUER $^{3}$, József NAGY ${ }^{4}$ \\ and Beáta PAPP ${ }^{5}$ \\ ${ }^{1}$ Belziger Str.37, D-10823 Berlin, Germany; *erzberger.peter@gmail.com \\ ${ }^{2}$ GINOP Sustainable Ecosystems Group, Centre for Ecological Research \\ H-8237 Tihany, Klebelsberg Kuno út 3, Hungary \\ ${ }^{3}$ Esslinger Str. 18, D-72124 Pliezhausen, Germany \\ ${ }^{4}$ The Museum and Library of Hungarian Agriculture \\ H-1146 Budapest, Városliget, Vajdahunyadvár, Hungary \\ ${ }^{5}$ Department of Botany, Hungarian Natural History Museum, \\ H-1431 Budapest, Pf. 137, Hungary
}

Erzberger, P., Németh, Cs., Sauer, M., Nagy, J. \& Papp, B. (2020): Plagiothecium platyphyllum (Bryophyta), a rare species in Hungary. - Studia bot. hung. 51(1): 25-40.

\begin{abstract}
All specimens deposited under the name Plagiothecium platyphyllum Moenk. in the bryophyte herbarium of the Hungarian Natural History Museum in Budapest (BP) were revised, along with some recent collections of the authors. As a result of this revision a majority of the specimens was found to belong to other species, and only ca $10 \%$ could be confirmed as $P$. platyphyllum, originating from eight locations, with recent collections from two sites only. The amended distribution of the species is mapped according to the Central European Mapping Scheme, and the corresponding specimens are cited in detail. The habitat of the Hungarian occurrences is characterised and compared to the literature. The morphological features of $P$. platyphyllum are described and illustrated by photographs, and the characters distinguishing this species from related taxa are discussed. We include an analytical key for the Hungarian species of the genus Plagiothecium.
\end{abstract}

Key words: distribution, habitat, herbarium revision, illustrated key, nematogones

\section{INTRODUCTION}

Plagiothecium platyphyllum was described by Mönkemeyer (1927). The author remarked: "P. platyphyllum ist durch Blattform und Zellnetz so gut ausgezeichnet, daß es, einmal erkannt, mit keiner anderen Art zu verwechseln ist" (MÖNKeMEYer 1927: 867; translation: P. platyphyllum is so well characterised by leaf shape and areolation that it cannot be confused with any other species, once recognised). However, the species has often been misidentified (SAUER and Mastracci 2001, Meinunger and Schröder 2007). Nyholm (1979: 643) writes: "This species is variable, confusing and often difficult to interpret. It seems to me probably to be a form between $P$. denticulatum and $P$. succulentum." 
In the two standard handbooks of Hungarian bryology (BOROs 1968, ORBÁN and VAJDA 1983), P. platyphyllum Mönk. has been reported from 14 floristical regions of Hungary: Zemplén Mts, Bükk Mts, Mátra Mts, Börzsöny Mts, Visegrád Mts, Vértes Mts, Balaton Uplands, Sopron Mts, Kőszeg Mts, Vendvidék, Örség, Vasi-hegyhát, Inner Somogy, Mecsek Mts. In apparent contradiction to such a wide distribution, it is characterised as rare ("ziemlich selten": Boros 1968: 386, "ritka": ORBÁN and VAJDA 1983: 486). According to the red list of Hungarian bryophytes (PAPP et al. 2010), P. platyphyllum is rated as data deficient (DD), and during the current bryophyte recording project (ERZBERGER and NÉMETH 2016), which encompasses all of the floristical regions mentioned above, the species was not found until very recently. When one of us (B. P.) collected a specimen of a large Plagiothecium at the Jeli Arborétum at Kám that seemed to fit the modern descriptions of the species, we began a more conscious search for it. We asked why it had not been detected during our earlier floristical fieldwork - had we perhaps not understood the correct characters used for identification? When we consulted the bryophyte collection in the Hungarian Natural History Museum in Budapest (BP), it turned out that 119 specimens were labelled P. platyphyllum, collected between 1923 and 1972 mainly by Á. Boros and L. Vajda within the present territory of Hungary, and constituting the vouchers for the regions published. We thought that a revision of these specimens might shed some light on possible differences between our concept of the species and that of the collectors.

In particular, we addressed the following questions:

- Which morphological characters allow a reliable identification of $P$. platyphyllum?

- What is the distribution of the species in the country, and in what habitats does it grow?

- What conclusions can be reached for the conservation of the species in Hungary?

\section{MATERIAL AND METHODS}

All specimens deposited as Plagiothecium platyphyllum in the bryophyte collection of the Hungarian Natural History Museum, Budapest (BP) and collected in present-day Hungary were revised, in total 123 specimens. (This number includes 4 specimens collected recently by B.P. in addition to the 119 historical specimens mentioned in the introduction.) For the purpose of comparison, some non-Hungarian material was also studied: a specimen collected by P.E. in the Austrian alps during a meeting of the BLAM (Bryologisch-Lichenologische Arbeitsgemeinschaft für Mitteleuropa) in 2001 (B-Erzberger 7502), as well as original material of the species collected in Germany by J. Bornmüller in Thuringia 
and determined by Wilhelm Mönkemeyer (Cryptogamae exsiccatae editae a Museo Hist. Natur. Vindobonensi 4055. Plagiothecium platyphyllum Mönkem. Deutschland: Thüringer Wald, feuchte Wände des Marderbach-Grundes bei Dietharz; leg. J. Bornmüller s.a., det. W. Mönkemeyer, BP 85532).

Nomenclature follows PAPP et al. (2010). The confirmed records of P. platyphyllum were mapped according to the Central European mapping scheme (BARTHA et al. 2015).

Microscopic photographs were taken with a Nikon Eclipse E-200 microscope and a QImaging MicroPublisher 3.3 RTV camera.

Due to difficulties in the delimitation of the species, we did not immediately reach a definite conclusion from our revision. During the first stage of the revision, of the 123 specimens held under the name Plagiothecium platyphyllum only 45 were thought to be likely candidates for true $P$. platyphyllum on the basis of modern accounts (LEWINSKY 1974, NyHOLM 1979, FAGERSTÉn 1998, SAUER and Mastracci 2001, SMith 2004, Meinunger and Schröder 2007) and comparison with the original material (see above). Therefore, we invited M.S. to participate in our revisionary work and showed him a small selection of the presumed candidates, 8 specimens from $\mathrm{BP}$ and two recent collections by the first author. It turned out that our concept of $P$. platyphyllum not only differed markedly from that of Boros and Vajda, but also from that of M.S., who confirmed only two of our determinations, and identified seven specimens as $P$. nemorale and one as $P$. denticulatum. In successive discussions we tried to arrive at more clear-cut criteria for the discrimination of $P$. platyphyllum. After studying the material for a second time, a further 30 critical specimens including recent collections were seen by M.S., and of these 11 were confirmed as $P$. platyphyllum, 18 were revised as $P$. nemorale and 1 as $P$. succulentum.

\section{RESULTS AND DISCUSSION}

The following specimens represent Plagiothecium platyphyllum.

(Abbreviations: leg. = collected by; det. = identified by; dupl. = duplicate; soc. = associated bryophytes; hb. = herbarium; s.n. $=$ without number; a.s.l. = above sea level).

Bükk Mts 7988.2: Comit. Borsod. In rupibus porphyr. sept. silvat. montis Nagy István erőse prope Nagyvisnyó, 900 m a.s.1., 09.08.1953, leg. Á. Boros, BP 145900. 7989.1: Comit. Borsod. In petrosis porphyr. fagetorum septent. montis Borovnyák prope Ómassa, 800-850 m a.s.l. 04.08.1953, leg. Á. Boros, det. Jedlička, BP 145898 (with a note: Plagiothecium platyphyllum Moenkemeyer Dr. 
Jos. Jedlička). - Börzsöny Mts 8079.4: Comit. Nógrád. In rupibus andesiticis umbrosis cacuminis montis Nagy-Hideg-hegy, montes Börzsöny, 22.04.1956, leg. L. Vajda, det. J. Jedlička, BP 47711, dupl. BP 57526, dupl. BP 145934 (with sporophytes), dupl. BP 57512 (soc. Plagiochila porelloides, Dicranum scoparium, Isothecium alopecuroides), dupl. BP 71680 (leg. et det.: 25.07.1966, L. Vajda). Pest County, Perőcsény, Nagyhideg-hegy, északi kitettségben, andezit kőgörgetegen, $\mathrm{N} 47^{\circ} 56^{\prime} 16.0^{\prime \prime}, \mathrm{E} 18^{\circ} 55^{\prime} 22.0$ ", $820 \mathrm{~m}$ a.s.l., 30.07.2016, leg. J. Nagy, det. P. Erzberger, hb. J. Nagy, dupl. B-Erzberger s.n., 19.10.2019, leg. J. Nagy, Cs. Németh, B. Papp, P. Erzberger, B-Erzberger 26995, 27000, 27001, 27004, 27006, 27009. - Vértes Mts 8575.4: Comit. Komárom. In faginetis ad Szentgyörgyvár prope Oroszlány, $300 \mathrm{~m}$ a.s.l. 07.10.1957, leg. Á. Boros, BP 145873 (with sporophytes). - Köszeg Mts 8665.1: Comit. Vas. Ad marginem rivuli vallis Walkgraben dictae Kőszeg, $400 \mathrm{~m}$ a.s.l. 09.10.1930, leg. A. Visnya, BP 146398, det. Jedlička (with sporophytes, with a note: "Meghatározás megerősítésre szorul. Kérek belőle 1934 márc. 11 Boros" - 'Identification needs confirmation. I would like a duplicate 11 March 1934 Boros'). - Vasi-hegyhát 8967.1: Comit. Vas. Ad rivulos alnetorum vallis rivi Koponyás versus Jeli pr. Kám, $200 \mathrm{~m}$ a.s.l. 12.05.1965, leg. Á. Boros, BP 146391. - Örség 9065.3: Comit. Vas. In alnetis versus silvam Csonka-erdő prope Szőce, 220 m a.s.l. 15.08.1954, leg. Á. Boros, BP 146386, det. Jedlička (with sporophytes, with a note: Plagiothecium platyphyllum Moenkemeyer Dr. Jos. Jedlička in litt). - Mecsek Mts 9974.2: Baranya County, Cserkút (Pécs), acidophilous Quercetum forest, N 4604' 01.7', E 1807' 43.7”, 190 m a.s.l. 18.05.2013, leg. et det.: B. Papp, BP 187139.

When we compare the results of our revision with the distribution published for Hungary in the 20th century (BOROs 1968, ORBÁN and VAJDA 1983), we must conclude that the latter was largely based on erroneous identifications, and instead of the 14 floristical regions we can confirm the species in only 7: Bükk Mts, Börzsöny Mts, Vértes Mts, Kőszeg Mts, Vasi-hegyhát, Örség, and Mecsek Mts (Fig. 1). Of 119 historical specimens labelled P. platyphyllum in BP, only 11 or fewer than $10 \%$ could be confirmed (Table 1 ). This clearly indicates that Boros, Vajda, and the Czech specialist Jedlička, who annotated a number of the specimens, had a wider concept of the species than modern authors.

It is therefore of fundamental importance to interpret correctly the diagnostic characters described in the literature.

Most modern accounts (TUOMIKoski et al. 1973, LEWINSKY 1974, Nyholm 1979, Sauer and Mastracci 2001, Smith 2004, Meinunger and SCHRÖDER 2007, CANO 2018) consider the presence of an extended group of thin-walled, isodiametric and often hyaline cells in the leaf apex as an important character of $P$. platyphyllum. These cells can produce rhizoids or propagula or become eroded in older leaves, and are therefore called rhizoid initials 


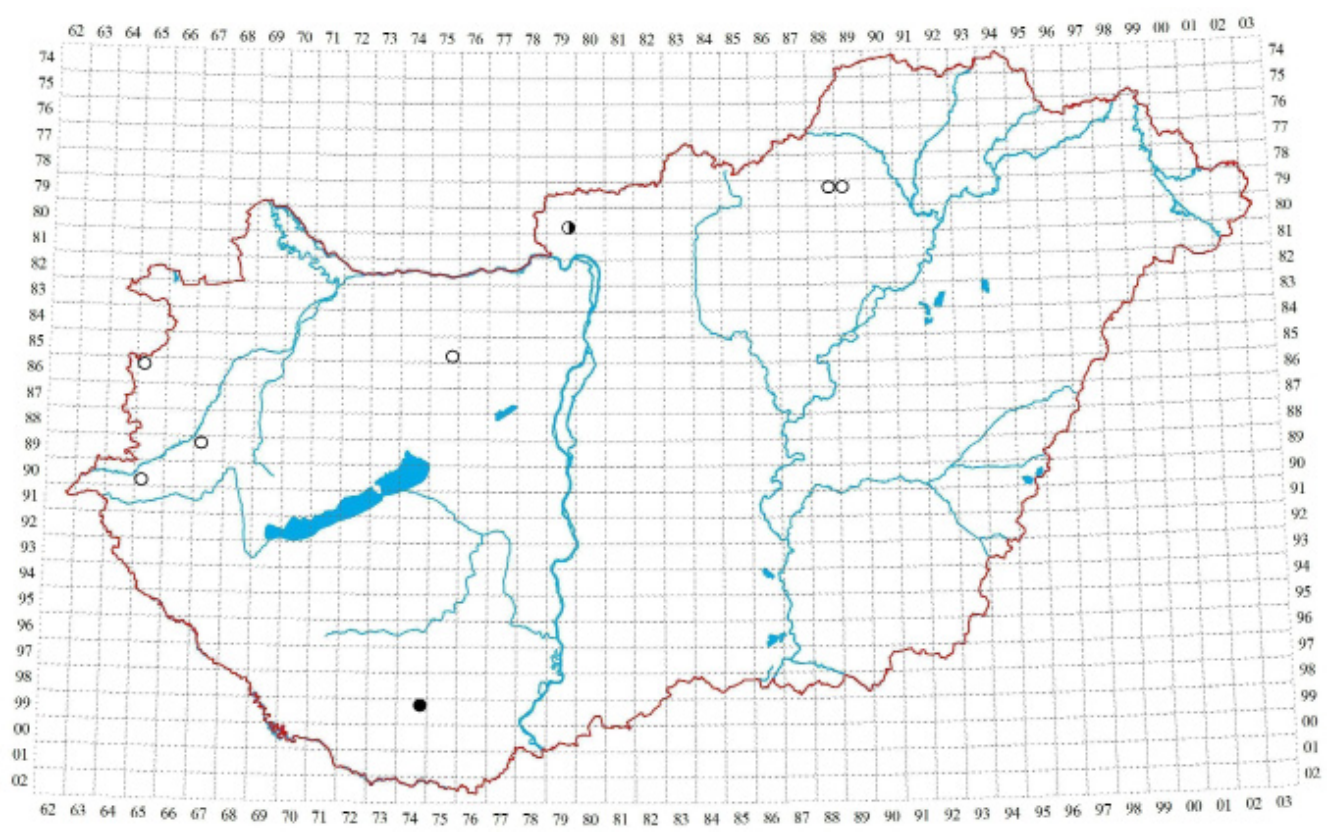

Fig. 1. Records of Plagiothecium platyphyllum in Hungary (open circles = before 1973; half solid circles $=$ before and after 1973; solid circles $=$ after 1973).

or nematogones (Fig. 2a-b, d-e). However, other species of the genus, viz. $P$. nemorale and $P$. succulentum, also can display this feature, although normally to a smaller extent. We studied this character in the original material determined by Moenkemeyer (Fig. 2a). When we found specimens with a similarly large group of rhizoid initials, we tentatively identified these also as $P$. platyphyllum. These plants, however, often had leaf cells that were much wider than the limits described in the literature (10-16 $\mu \mathrm{m}$ : SAUER and MASTRACCI 2001, or even less, e.g. 10-13 $\mu \mathrm{m}$ : CANO 2018). We tentatively assumed that this character might perhaps be more variable than reported in the literature. It was only with the help of M.S. that we realised that in many cases $P$. nemorale was at hand (Fig. 2c). Unfortunately, some recently published data on the occurrence of $P$. platyphyllum in Örség (Szőce), Vasi-hegyhát (Kám), and Zala (Vétyem) were based on some of these critical specimens that were later revised to P. nemorale (PAPP and SZURDOKI 2018), and they should therefore be deleted. Interestingly, some historical collections from Szőce and Kám are true P. platyphyllum (see above), but no recent collections of this species have been made in these localities. At present, the only recently collected specimens of P. platyphyllum in Hungary are from the Börzsöny Mts (Nagy-Hideg-hegy, leg. J. Nagy et al.) and the Mecsek 
Mts (Cserkút, leg. B. Papp). In October 2019 four of us (all authors except M. S.) went on an excursion to the Börzsöny site (Fig. 7b). However, we did not succeed in recognising the species in the field. Fortunately, subsequent microscopic examination showed that among much $P$. nemorale, $P$. platyphyllum was also present in good quantity, and we had collected it inadvertently (B-Erzberger 26995, 27000, 27001, 27004, 27006, 27009, Fig. 6).
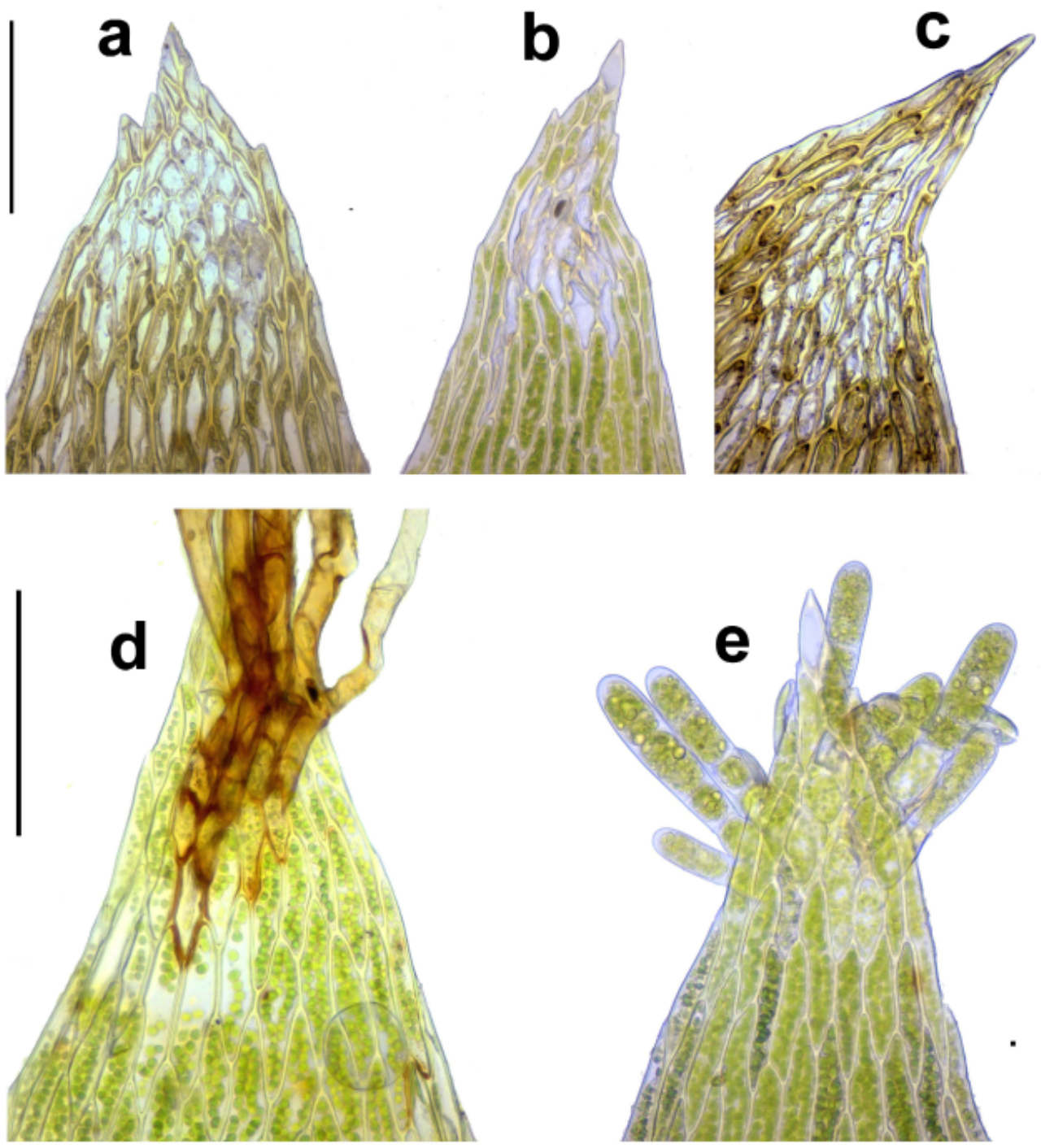

Fig. 2. Leaf tips of Plagiothecium species. - a, b, d, e: P. platyphyllum (a = original material, Thüringer Wald, Dietharz, det. Moenkemeyer, BP 85532; b, d, e = Börzsöny Mts, Nagy-Hideg-hegy, B-Erzberger 27001). - c: P. nemorale (Bakony Mts, Uzsa, BP 145878). Scale bar $100 \mu \mathrm{m}$. Observe rhizoid initials (nematogones) (a, b, c); denticulations (a, b); leaf borne rhizoids (d) and propagula (e)

(photos: Cs. Németh). 
It appears to be relevant that no mention of the nematogones can be found in the taxonomic literature available at the time of Boros and Vajda (MÖNKEMEYER 1927), and in particular in the publications of the Czech specialist Jedlička, who annotated many specimens in BP and on whom the Hungarian bryologists obviously relied to some extent (JEDLIČKA 1948, 1950). This may in part explain the difficulties in recognising the true P. platyphyllum at the time of Boros and Vajda. Of the 26 specimens annotated by Jedlička as $P$. platyphyllum, $9(35 \%)$ were confirmed as this species, but 14 (54\%) were revised to $P$. nemorale and $3(11 \%)$ to $P$. succulentum.

The production of propagula by the nematogones, which we observed in the freshly collected material from the Börzsöny site (Fig. 2e), is also reported by Tuomikosky (1973), Fagerstén (1998) and Huber (1984), whereas e.g. LEWINSKY (1974) and CANO (2018) state that vegetative propagation by fusiform brood bodies is unknown or has not been observed in P. platyphyllum. Obviously this is an infrequent phenomenon not regularly encountered. Among the Hungarian species of Plagiothecium, only P. latebricola commonly produces such fusiform propagula at the leaf tips (ERZBERGER and BARÁtH 2017, LEWINSKY 1974).

From the number of specimens revised as other species of the genus (Table $1)$ it is evident that $P$. nemorale and $P$. succulentum are morphologically most closely related to $P$. platyphyllum and therefore most likely to be confused with it. As regards the decurrent alar cells, $P$. platyphyllum and $P$. denticulatum share the character state that these cells are in part inflated, although this holds only for the outer cell row in P. platyphyllum (Fig. 3a-c), whereas in P. denticulatum inflated cells are present throughout (Fig. 3d). In Table 2 we compare the morphological characters relevant for the identification of these species.

Table 1. Revision of the 119 historical specimens inserted in Plagiothecium platyphyllum.

\begin{tabular}{lc}
\hline species named as result of revision & no of specimens \\
\hline Plagiothecium cavifolium (Brid.) Z. Iwats. & 16 \\
Plagiothecium curvifolium Schlieph. ex Limpr. & 1 \\
Plagiothecium denticulatum (Hedw.) Schimp. & 10 \\
Plagiothecium laetum Schimp. & 2 \\
Plagiothecium nemorale (Mitt.) A. Jaeger & 58 \\
Plagiothecium platyphyllum Mönk. & 11 \\
Plagiothecium succulentum (Wilson) Lindb. & 20 \\
indet. (poor material) & 1 \\
\hline
\end{tabular}




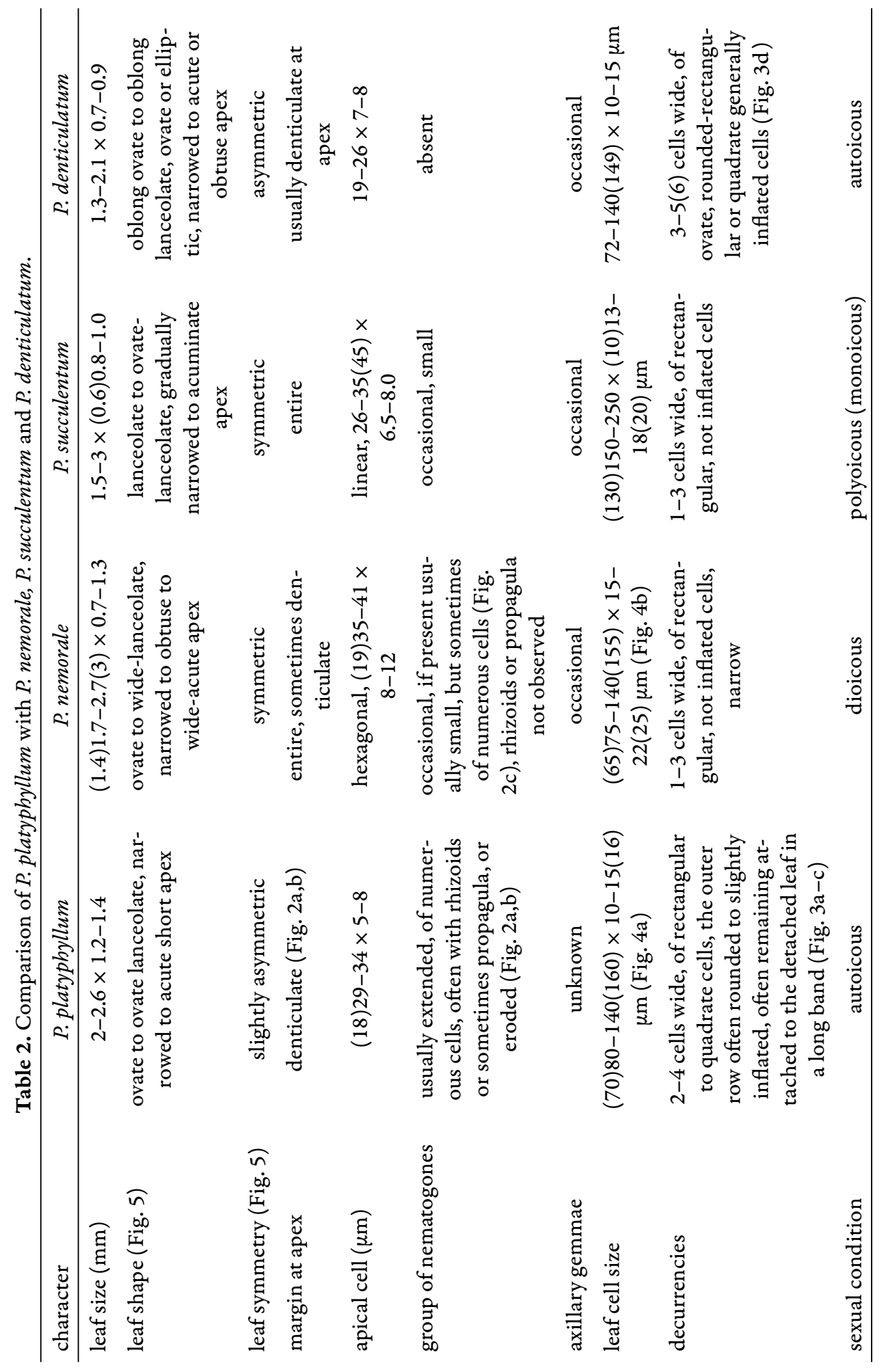


In conclusion, Plagiothecium platyphyllum can be recognised by the combination of the following characters:

- large plants (Fig. 6);

- an extended group of rhizoid initials in the leaf apex, often eroded away (Fig. 2a-b, d-e);

- slight, but sharp denticulations at the leaf apex (not always present) (Fig. $2 a-b)$;

- a long group of decurrent cells that often remains attached to the leaf when removed from the stem, 2-4 cells wide, at least some of the outer cells with rounded outlines (Fig. 3a-c);

- mid leaf cells not wider than $15 \mu \mathrm{m}$ (Fig. 4a);

- slightly asymmetric leaves tapering evenly to an acute point (Fig. 5a).

These characters are, however, not always fully and equally well developed.

\section{Habitat}

According to the information included on the specimen labels, in Hungary P. platyphyllum grows in two types of habitat, according to elevation. At lower elevations, at $400 \mathrm{~m}$ a.s.l. or below, the collections are from the vicinity of water courses or wetlands (particularly Alder carr). For instance at Cserkút the species was found near a spring bog (Cardamino-Montion Br-Bl. 1926) formed along a temporary rivulet in an acidophilous oak forest (Fig. 7a). Philonotis caespitosa, Plagiomnium undulatum, Plagiothecium denticulatum, Poblia nutans, Rhizomnium punctatum and Sphagnum fimbriatum can be mentioned as associated bryophytes in the surrounding area.

At higher elevations, 820-900 m a.s.l., the species was found in forests, in shaded, moist situations, on mainly acidic rock or stones (porphyry, andesite) often with a northern exposition near the summits of the northern mountain range (Bükk Mts, Börzsöny Mts: Fig. 7b). Apart from P. nemorale, associated bryophytes at the Börzsöny site (Nagy-Hideg-hegy) include Anomodon rugelii, Barbilophozia barbata, Brachythecium geheebii, Jamesoniella autumnalis, Pseudoleskea saviana and Sanionia uncinata.

According to the literature, P. platyphyllum is a calcifuge moss of wet, shaded habitats in montane areas (springs, wet rock crevices, by waterfalls and on stream banks: BlOCKEEL et al. 2014, SMITH 2004, SAUER and MASTRACCi 2001, MEINUNGer and SCHRÖDER 2007). This type of habitat corresponds to the Hungarian occurrences in the Bükk Mts and Börzsöny Mts. However, the growth sites in the colline area (Vértes Mts, Köszeg Mts, Vasi-hegyhát, Örség and Mecsek Mts) differ from the typical habitat in other parts of Europe. They may represent a special type of lowland site with montane affinities ("Mikroklimawinkel" in 
Boros 1968), favoured perhaps by the cooler climate of western Hungary with greater precipitation, and by edaphic factors like the gravel deposits in Örség and Vasi-hegyhát (Boros 1968). According to PlăMADĂ (2001), in Romania $P$. platyphyllum has also been recorded in the lowlands, although rarely.

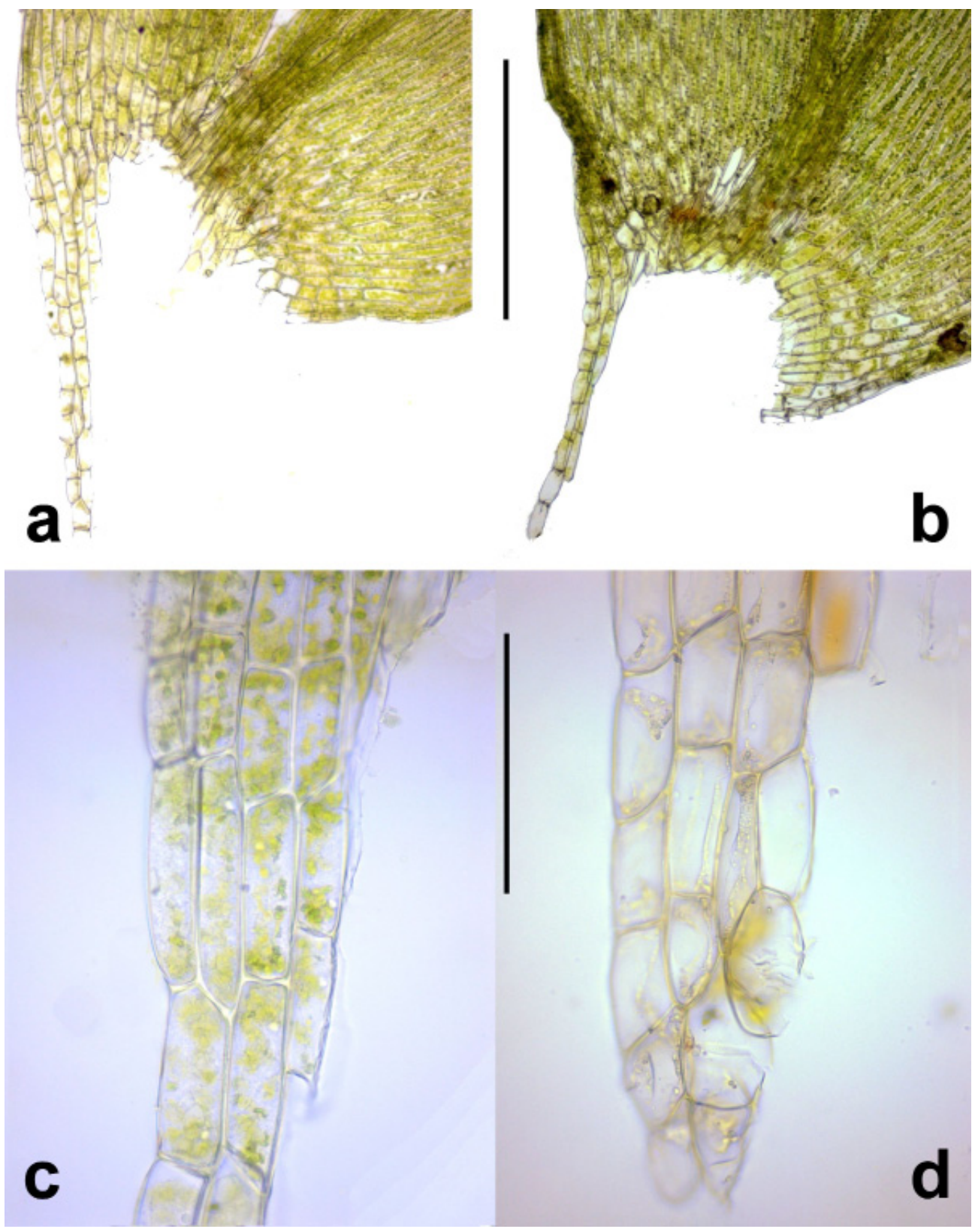

Fig. 3. Decurrent alar cells of Plagiothecium species: $a-c=P$. platyphyllum (B-Erzberger 27001); $\mathrm{d}=P$. denticulatum (Vértes, Pusztavám B-Erzberger 15102). Scale bars a-b: $200 \mu \mathrm{m}, \mathrm{c}-\mathrm{d}: 100 \mu \mathrm{m}$ (photos: Cs. Németh). 


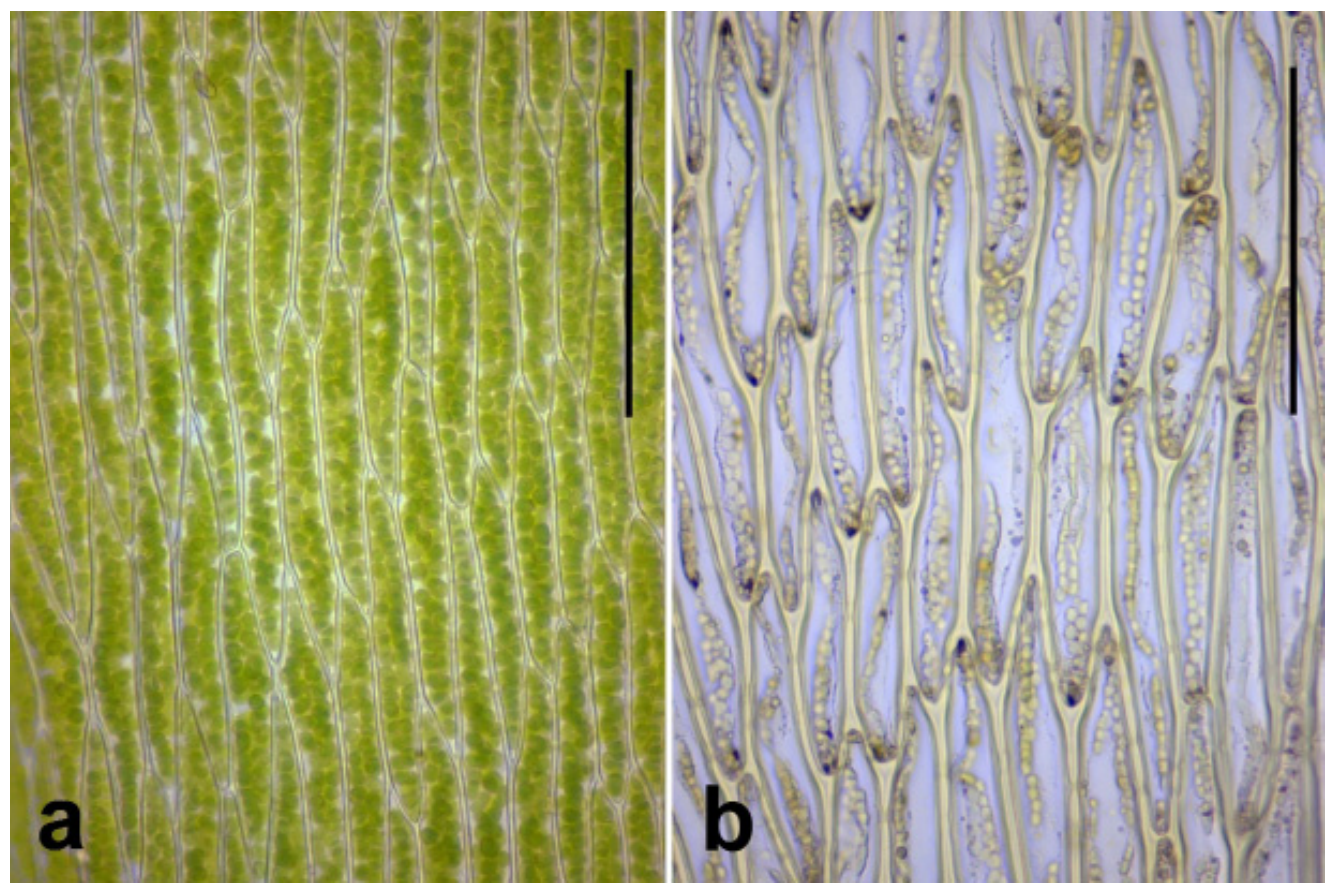

Fig. 4. Leaf cells of Plagiothecium species: $\mathrm{a}=$ P. platyphyllum (B-Erzberger 27001); $\mathrm{b}=$ P. nemorale (Vértes, Pusztavám, CsN 5434). Scale bar $100 \mu \mathrm{m}$ (photos: Cs. Németh).
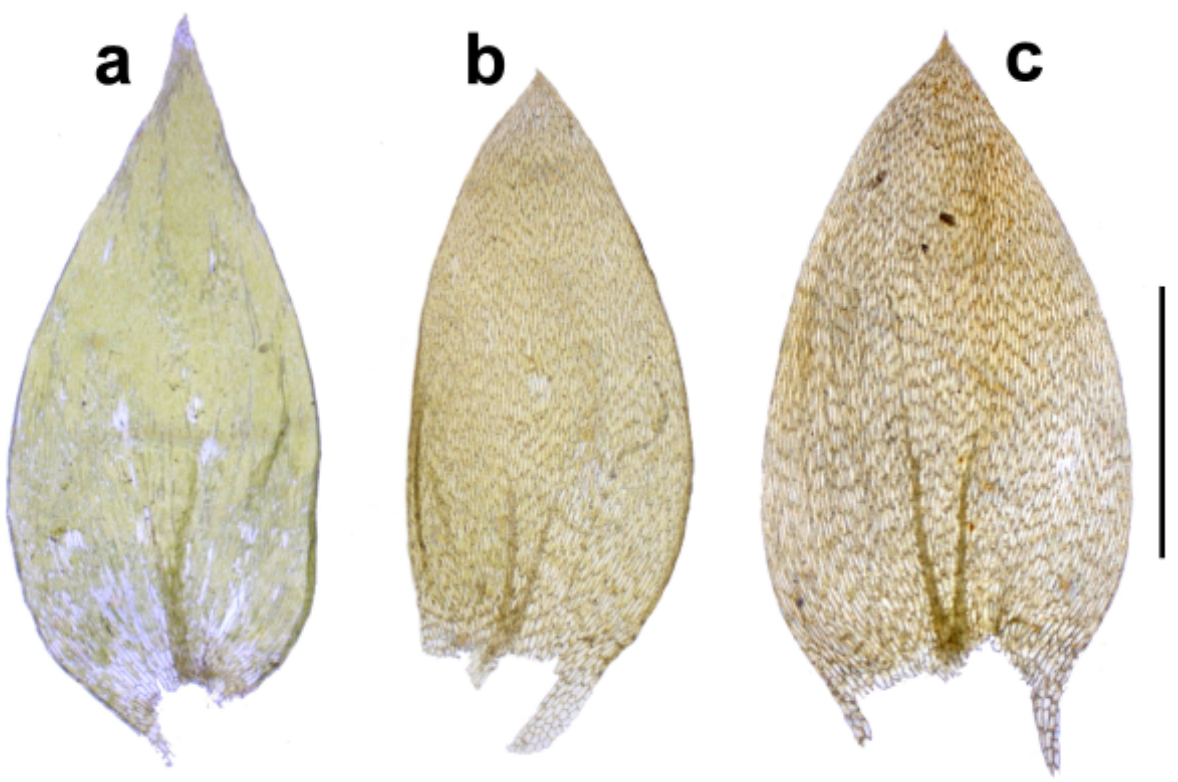

Fig. 5. Leaves of Plagiothecium species: $\mathrm{a}=P$. platyphyllum (B-Erzberger 27001); $\mathrm{b}=$ P. denticulatum (Bakony, Farkasgyepü, B-Erzberger 16302); c = P. nemorale (Vértes, Pusztavám, CsN 5434). Scale bar $1 \mathrm{~mm}$ (photos: Cs. Németh). 


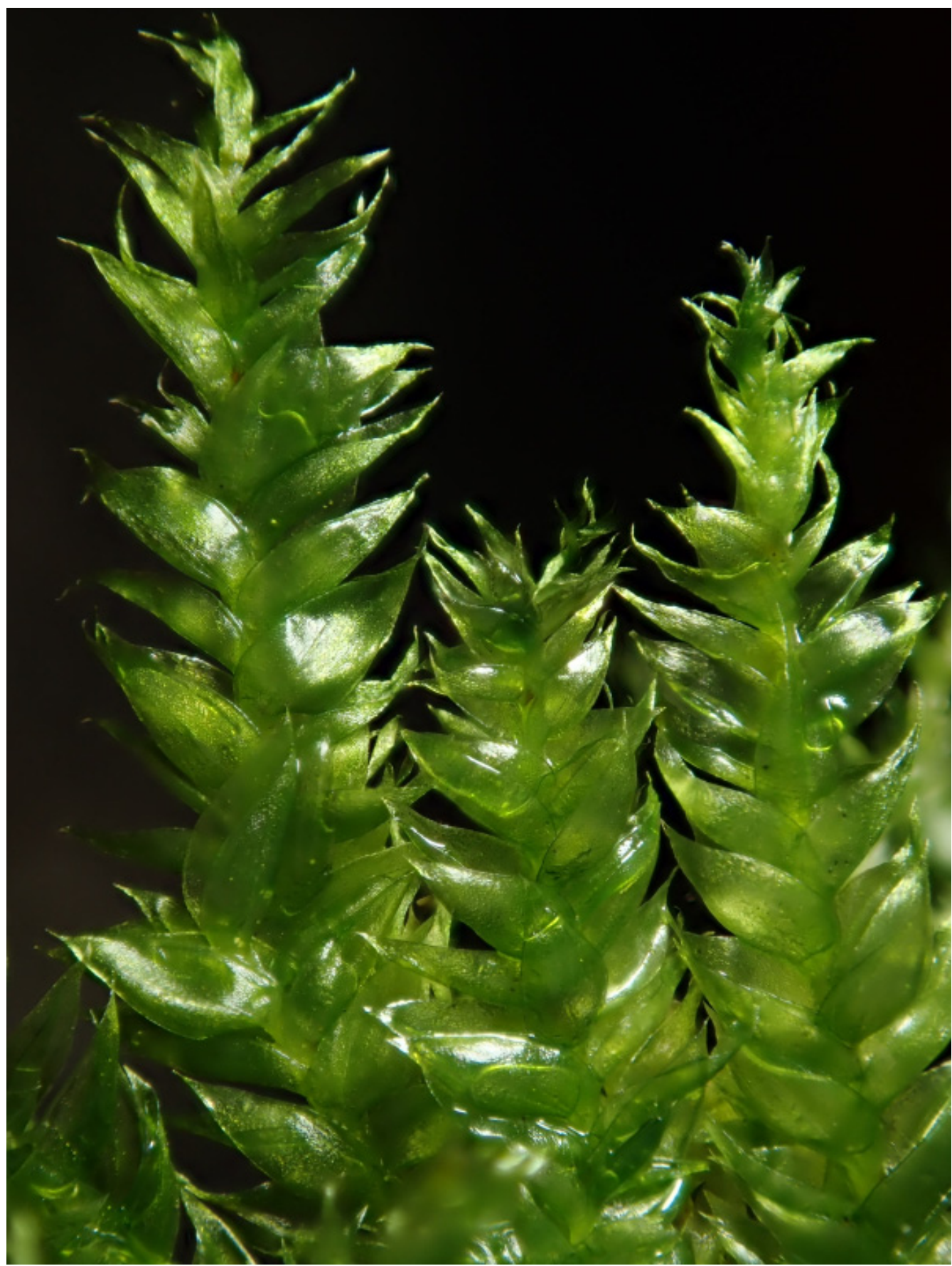

Fig. 6. Habit of Plagiothecium platyphyllum (B-Erzberger 27001) (photo: Cs. Németh). 


\section{Key to Hungarian species of Plagiothecium (mainly based on LEWINSKY 1974)}

1 Leaves whitish green, 2-5 mm long, imbricate, strongly transversely undulate; decurrent alar cells with straight outer walls; on forest soil ........................... P. undulatum (Hedw.) Schimp.

- $\quad$ Plants without this combination of characters ................................................................................ 2

2 Median laminal cells narrow, $<10 \mu \mathrm{m}$ wide; small plants, usually only $2-3 \mathrm{~cm}$ long ............. 3

- $\quad$ Median laminal cells $>10 \mu \mathrm{m}$ wide; medium-sized to large plants ............................................. 5

3 Leaves $0.9-1 \mathrm{~mm}$ long and ca. $0.35 \mathrm{~mm}$ wide, symmetric, gradually acuminate to a long point, often with uniseriate gemmae and rhizoids at the tip; laminal cells $5(-8) \mu \mathrm{m}$ wide

P. latebricola Schimp.

- Leaves longer and wider (mostly $>0.5 \mathrm{~mm}$ wide), asymmetric, apex less longly drawn out, usually without gemmae (but gemmae frequent in leaf axils); laminal cells wider ........................ 4

4 Leaf apices plane; leaves asymmetric usually with one curved and one straight side, to $1.2 \mathrm{~mm}$ long, alar cells decurrent in 1-2 rows, not clearly delimited, not auriculate, with straight outer walls, rectangular

P. laetum Schimp.

- Leaf apices curved downward towards substrate when moist; leaves asymmetric with two curved sides, $>1.2 \mathrm{~mm}$ long, alar cells forming a distinct group, decurrent in 2-4(5) rows, mostly somewhat auriculate, often with weakly bulging outer walls, isodiametric or rectangular; capsule horizontal to inclined, often gibbous ............... P. curvifolium Schlieph. ex Limpr.

5 Decurrent alar cells inflated, oval to rounded, with bulging walls, sometimes only a few cells rounded and most cells rectangular or quadrate; laminal cells not wider than $16 \mu \mathrm{m}$............ 6

- Alar cells not inflated, the decurrent cells rectangular, not rounded; laminal cells wider than

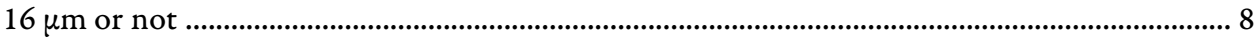

6 Alar cells mostly rectangular or quadrate, forming a long triangular group decurrent in 2-4 rows along stem and often remaining on the detached leaf, at least some of the outer cells with rounded outlines; apical part of lamina usually with a group of thin-walled short cells (rhizoid initials) often eroded; some leaves only weakly asymmetric; large plants to $10 \mathrm{~cm}$ long

P. platyphyllum Mönk.

- Most alar cells strongly inflated, rounded, forming an oval group usually less long, often wider, decurrent in 3-4(6) rows; leaves without rhizoid initials at apex; all leaves distinctly asymmetric; medium-sized plants

7 Laminal cells in \pm distinct transverse rows, therefore leaves sometimes transversely undulate when moist; margins at apex often completely without denticulations; leaves $2.5-4 \mathrm{~mm}$ long, strongly complanate, strongly asymmetric, at least some with one straight and one curved side; decurrent alar cells in 4-6(8) rows; plants of wet habitats

P. ruthei Limpr.

- Laminal cells not in transverse rows, leaves not transversely undulate when moist; margins at apex often denticulate; leaves 1.5-2.5(3) mm long, less strongly complanate, asymmetric, mostly with both sides curved; decurrent alar cells in 3-5 rows; plants of humid, but not particularly wet habitats ............................................................. P. denticulatum (Hedw.) Schimp.

8 Leaves \pm symmetric, concave; plants julaceous, decumbent (examine older plants; young plants of other species can look similar); mid-leaf cells (8)10-12(15) $\times 65-120(150) \mu \mathrm{m}$........

P. cavifolium (Brid.) Z. Iwats.

- $\quad$ Leaves symmetric to \pm asymmetric, plane; mid-leaf cells wider or longer ................................. 9

9 Majority of mid-leaf cells longer than $150 \mu \mathrm{m}$ and 10-20 $\mu \mathrm{m}$ wide (7-10 times as long as wide), not in transverse rows; apical end cell linear, elongate; leaf apex occasionally with rhizoid initials P. succulentum (Wilson) Lindb.

- $\quad$ Mid-leaf cells 15-22(25) × (65)75-140(155) $\mu \mathrm{m}$ (4-6 times as long as wide) in \pm transverse rows; apical end cell rhomboidal; leaf apex usually with (few) rhizoid initials

P. nemorale (Mitt.) A. Jaeger 


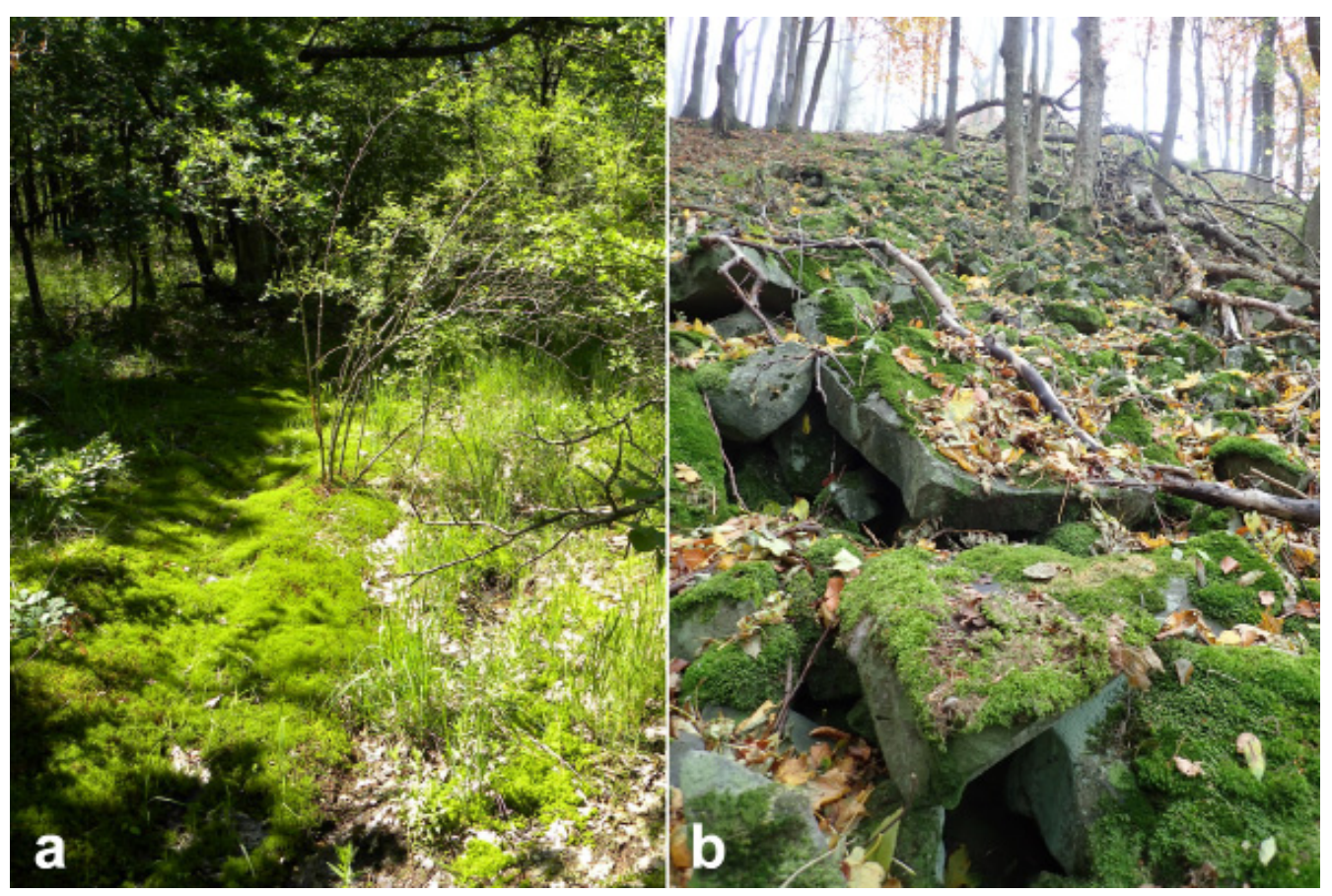

Fig. 7. Habitat of Plagiothecium platyphyllum: a = at Cserkút (Mecsek) (photo: B. Papp); $\mathrm{b}=$ at Nagy-Hideg-hegy (Börzsöny) (photo: Cs. Németh).

\section{Conservation aspects}

According to the latest European Red List of bryophytes (HoDGETTs et al. 2019), P. platyphyllum is rated as LC (least concern). In Hungary, the species was in the DD (data-deficient) category in PAPP et al. (2010), but since two extant populations have been detected recently, this category is no longer applicable.

The two known populations are very small, each of them has less than 50 mature individuals (less than 50 occupied quadrats of $1 \times 1 \mathrm{~m}^{2}$ ). According to the IUCN criteria (IUCN Standards and Petitions Subcommittee 2017), with a maximum total number of individuals less than 250 and in each subpopulation less than 50 individuals $P$. platyphyllum would qualify as critically endangered (CR) C2ab(i). Fortunately, the known occurrences are situated in protected areas: the Börzsöny Mts are within the Duna-Ipoly National Park, and the locality near Cserkút belongs to the Duna-Dráva National Park. However, since the species occurs in habitats that are highly sensitive to climate change (e.g. rising temperatures in mountain areas, drying of temporary watercourses in the lowlands) a decline in population size and habitat quality can be projected. 
Since the species cannot be recognised with certainty in the field, it is probably overlooked as the common $P$. nemorale. Hopefully, the present account will contribute to a better knowledge of the species and stimulate further discoveries, leading to a re-evaluation of its threat status in Hungary.

Acknowledgements: Thanks are due to Péter Ódor for allowing us to use his photomicroscope, and to Tom L. Blockeel for improvements to the English language.

Összefoglaló: A Plagiothecium platyphyllum a magyar mohaflóra viszonylag nehezen azonosítható, ebből adódóan kissé félreismert faja. A határozási nehézségeket tükrözi, hogy a Magyar Természettudományi Múzeum moha gyüjteményének $P$. platyphyllum-ként cédulázott példányai (119) közül mindössze $10 \%$ bizonyult helyesnek, a fennmaradó példányok pedig mind más Plagiothecium fajhoz tartoztak ( $P$. cavifolium, $P$. curvifolium, $P$. laetum, $P$. nemorale, $P$. succulentum). A határozási nehézségek ellenére a $P$. platyphyllum viszonylag nagy termete, kissé aszimmetrikus, egyenletesen hegyes csúcsba keskenyedő levele, kissé fogazott levélcsúcsa, a levélcsúcsi részen fejlődő rhizoid kezdeményei, a szárra hosszan lefutó, 2-4 sejt szélességü levélalapi sejtjei, valamint a 15 $\mu \mathrm{m}$-nél nem szélesebb levélközépi sejtjei alapján mégis nagy biztonsággal azonosítható. A növénytári historikus példányok revíziója, valamint a szerzők recens gyüjtései alapján a fajnak mindössze nyolc biztos magyarországi előfordulása ismert a Bükk, a Börzsöny, a Vértes, a Kőszegi-hegység, a Vasi-hegyhát, az Örség, valamint a Mecsek területéről. A két jelenleg ismert populáció (Börzsöny, Nagy-Hideg-hegy; Mecsek, Cserkút) értékelése alapján a $P$. platyphyllum IUCN vörös listás új besorolására a kipusztulással veszélyeztetett $(\mathrm{CR})$ kategóriát tekintjük indokoltnak.

\section{REFERENCES}

Bartha, D., Király, G., Schmidt, D., Tiborcz, V., Barina, Z., Csiky, J., Jakab, G., Lesku, B., Schmotzer, A., Vidéki, R., Vojt kó, A. and Zólyomi, Sz. (eds) (2015): Magyarország edényes növényfajainak elterjedési atlasza (Distribution atlas of vascular plants of Hungary). University of West Hungary Press, Sopron, $330 \mathrm{pp}$.

Blockeel, T. L., Bosanquet, S. D. S., Hill, M. O. and Preston, C. D. (2014): Atlas of British and Irish bryophytes. Vol. 2. Pisces. - British Bryological Society, Newberry, 652 pp.

Boros, Á. (1968): Bryogeographie und Bryoflora Ungarns. - Akadémiai Kiadó, Budapest, 466 pp.

Cano, M. J. (2018): Plagiothecium Hedw. - In: Guerra, J., Cano, M. J. and Brugués, M. (eds):

Flora Briofítica Ibérica, vol. 6. Sociedad Española de Briología, Murcia, pp. 276-294.

ERZBERger, P. and BARÁTH, K. (2017): Plagiothecium latebricola Schimp. - a new member of the Hungarian bryoflora. - Studia bot. hung. 48(2): 189-197.

https://doi.org/StudBot.2017.48.2.189

Erzberger, P. and Németh, Cs. (2016): Bryophyte recording in Hungary - results 2012-2015. Book of Abstracts, 11th Int. Conf. "Advances in research on the flora and vegetation of the Carpato-Pannonian region”, Budapest, 12-14 February 2016 (lecture), p. 17.

FAGERSTÉN, R. (1998): Taxonomy, distribution and ecology of Plagiothecium platyphyllum Mönk. (Musci, Plagiotheciaceae); an example of an endangered moss in spring-fed habitats. - Mem. Soc. Fauna Flora Fennica 74: 25-39.

Hodgetts, N., Cálix, M., Englefield, E., Fettes, N., García Criado, M., Patin, L., Nieto, A., Bergamini, A., Bisang, I., Baisheva, E., Campisi, P., Cogoni, A., Hallingbäck, 
T., Konstantinova, N., Lockhart, N., Sabovljević, M., Schnyder, N., Schröck, C., Sérgio, C., Sim Sim, M., Vrba, J., Ferreira, C. C., Afonina, O., Blockeel, T., Blom, H., Caspari, S., Gabriel, R., Garcia, C., Garilleti, R., González Mancebo, J., Goldberg, I., Hedenäs, L., Holyoak, D., Hugonnot, V., Huttunen, S., Ignatov, M., Ignatova, E., Infante, M., Juutinen, R., Kiebacher, T., Köckinger, H., KuČera, J., Lönnell, N., Lüth, M., Martins, A., Maslovsky, O., Papp, B., Porley, R., Rothero, G., Söderström, L., Ştefanuț, S., Syrjänen, K., Untereiner, A., VáŇa, J., Vanderpoorten, A., Vellak, K., Aleffi, M., Bates, J., Bell, N., Brugués, M., Cronberg, N., Denyer, J., Duckett, J., During, H. J., Enroth, J., Fedosov, V., Flatberg, K.-I., Ganeva, A., Gorski, P., Gunnarsson, U., Hassel, K., Hespanhol, H., Hill, M., Hodd, R., Hylander, K., IngerpuU, N., LaAKa-Lindberg, S., Lara, F., Mazimpaka, V., Mežaka, A., Müller, F., Orgaz, J. D., Patiño, J., Pilkington, S., Puche, F., Ros, R. M., Rumsey, F., Segarra-Moragues, J. G., Seneca, A., Stebel, A., Virtanen, R., Weibull, H., Wilbraham, J. and Żarnowiec, J. (2019): A miniature world in decline: European red list of mosses, liverworts and hornworts. - IUCN, Brussels, 87 pp. https://doi.org/10.2305/IUCN.CH.2019.ERL.2.en

Huber, H. (1984): Plagiothecium. - Naturräumliches Inventar der Schweizer Moosflora, 4 pp. (mscr.) IUCN Standards and Petitions Subcommittee (2017): Guidelines for using the IUCN Red List Categories and Criteria. Version 13. - Prepared by the Standards and Petitions Subcommittee, 108 pp. http://cmsdocs.s3.amazonaws.com/RedListGuidelines.pdf

JedličKa, J. (1948): Monographia specierum europaearum gen. Plagiothecium s. s. Partis specialis I. Summarium. - Publ. Fac. Sci. Univ. Masaryk, Brno, pp. 3-45. [in Latin].

JEDLIČKA, J. (1950): Monographia specierum europaearum gen. Plagiothecium s. s. Icones. (Tabulae photographicae 1-7 et tabulae I-XXXII). - Publ. Fac. Sci. Univ. Masaryk, Brno [in Latin].

Lewinsky, J. (1974): The family Plagiotheciaceae in Denmark. - Lindbergia 2: 185-217.

Meinunger, L. and SCHRöder, W. (2007): Verbreitungsatlas der Moose Deutschlands. Band 3. Regensburgische Botanische Gesellschaft, Regensburg, 709 pp.

MöNKEMEYER, W. (1927): Dr. L. Rabenhorsts Kryptogamen-Flora von Deutschland, Österreich und der Schweiz, Vierter Band, Ergänzungsband: Die Laubmoose Europas Andreaeales - Bryales. Akademische Verlagsgesellschaft, Leipzig, 956 pp.

Nyноцм, E. (1979): Illustrated moss flora of Fennoscandia. Fasc. 5. - Botanical Society of Lund, Lund, 647 pp.

Orbán, S. and VAJdA, L. (1983): Magyarország mohaflórájának kézikönyve. - Akadémiai Kiadó, Budapest, $518 \mathrm{pp}$.

PAPP, B. and SzURDOKI, E. (2018): Bryophyte flora of the forests of Vétyem and Oltárc protected areas (Zala County, W Hungary). - Studia bot. hung. 49(1): 83-96. https://doi.org/10.17110/StudBot.2018.49.1.83

PAPp, B., Erzberger, P., Ódor, P., Hock, Zs., Szövényi, P., SZurdoki, E. and Tóth, Z. (2010): Updated checklist and red list of Hungarian bryophytes. - Studia bot. hung. 41: 31-59.

PLĂMADĂ, E. (2001): Monographische Untersuchung der Familie Plagiotheciaceae in Rumänien. - Linzer biol. Beitr. 33(2): 1227-1260.

Sauer, M. and Mastracci, M. (2001): Plagiothecium Schimp. - In: Nebel, M. and Philippi, G. (eds): Die Moose Baden-Württembergs, II. Ulmer Verlag, Stuttgart, pp. 434-449.

Smith, A. J. E. (2004): The moss flora of Britain and Ireland. 2nd ed. - University Press, Cambridge, $1012 \mathrm{pp}$.

Tuomikoski, R., Koponen, T. and Aнti, T. (1973): The mosses of the island of Newfoundland. - Ann. Bot. Fenn. 10: 217-264.

(submitted: 05.03.2020, accepted: 21.05.2020) 